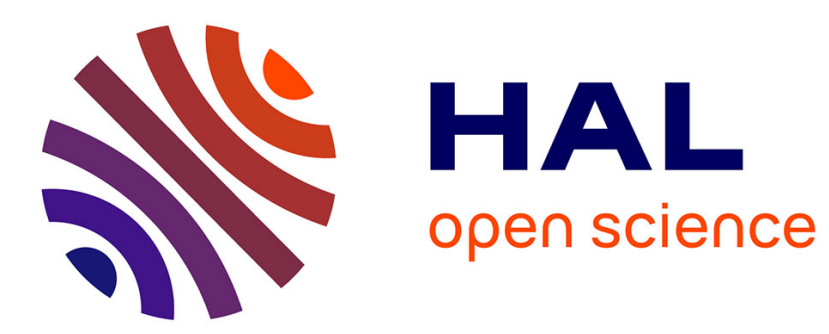

\title{
Channelling Protest in Illiberal Regimes: The Cuban Case since the Fall of the Berlin Wall \\ Marie Laure Geoffray
}

\section{To cite this version:}

Marie Laure Geoffray. Channelling Protest in Illiberal Regimes: The Cuban Case since the Fall of the Berlin Wall. Journal of Civil Society, 2014. halshs-01726590

\section{HAL Id: halshs-01726590 \\ https://shs.hal.science/halshs-01726590}

Submitted on 8 Mar 2018

HAL is a multi-disciplinary open access archive for the deposit and dissemination of scientific research documents, whether they are published or not. The documents may come from teaching and research institutions in France or abroad, or from public or private research centers.
L'archive ouverte pluridisciplinaire HAL, est destinée au dépôt et à la diffusion de documents scientifiques de niveau recherche, publiés ou non, émanant des établissements d'enseignement et de recherche français ou étrangers, des laboratoires publics ou privés. 


\title{
Channelling Protest in Illiberal Regimes: The Cuban Case since the Fall of the Berlin Wall
}

\author{
MARIE LAURE GEOFFRAY \\ IHEAL, Sorbonne Nouvelle/Paris 3, Paris, France \\ Institutional affiliation \\ Correspondence Address: 28 rue Saint Guillaume, 75007 Paris, France
}

\begin{abstract}
The article argues that we need to analyse the way protest is being channelled in illiberal regimes, in order to understand how they manage to prevent the emergence of political challengers to authoritarian rule. Drawing on the Cuban case, the text shows that such channelling allows the intentional as well as unintentional disconnection between social and cultural claims on the one hand and political claims on the other hand, which in turn isolates political dissidents from other types of dissenters (for instance in the cultural sphere), thus preventing a more unified contentious movement from emerging.
\end{abstract}

KEY WORDS: Channelling protest, illiberal regimes, Cuba

The social and political phenomena of the 'Arab Springs' have shifted scholars' attention from the persistence of authoritarian rule to new paradigms of collective action and new analyses of the breakdown of authoritarian regimes. Now, elsewhere across the world, illiberal regimes do manage to remain in power and even consolidate, as it is the case in Belarus, China or Russia for instance. It is thus necessary to continue to deepen our understanding of the mechanisms of power that allow for the reproduction of authoritarian governments. One such mechanism is the channelling of citizen's social and political claims towards relatively harmless and largely de-politicized forms of participation. Channelling claims (Earl, 2003, 2004, 2006) is a way for governments to manage contention, both repressing selectively and making 'tactical concessions' (Risse, Ropp \& Sikkink, 1999), so as to allow for some protest to be voiced while avoiding overall regime change (Cavatorta, 2013).

Cuba is a good case in point. It is indeed one of the few communist regimes that has managed to survive the disintegration of the Soviet Union, despite widespread expectations that it would not. And it has done so with relatively few market reforms, compared with China or Vietnam, and with very little social and political protest.

With growing poverty and inequalities (Espina 2008, 2011), regime survival in Cuba cannot be explained by the coining of an authoritarian 'social contract', i.e. social welfare is traded for political compliance (Bialer, 1980; Hewett, 1988) as in China or Vietnam today. That might have been the case until 1989 (Perez-Stable, 1999), but it has become harder for most Cubans to make ends meet since the 1990s. Some thus focus on the regime's clientele and use the metaphor of the 'gatekeeper State', to emphasize the fact that economic 
opportunities are given to specific segments of the population, especially the military (Corrales, 2004), to ensure their political support. In order to complement those analyses, I propose to shift the focus towards political and cultural dynamics, so as to understand not only how the government has managed to secure support among certain categories of the Cuban people, but also how it has managed to keep social and political protest under control.

Some scholars have already emphasized the politics of cultural liberalization, implemented since the mid-1990s (Fernandes, 2006; Hernandez Reguant, 2009), in order to explain renewed popular support for the revolutionary leadership. There were indeed often more opportunities to voice criticism in the cultural sphere than in the political sphere in communist regimes (Feher, Heller \& Markus, 1983; Popa, 2001; Balasinski, 2002). Cuba is no exception, although censorship and arbitrariness never disappeared (Vaissié, 1999, 2008). In Cuba, those opportunities increased during the 1990s thanks to the authorities' politics of laissez faire and integration into the global cultural market. These politics of laissez faire could have led to an expansion of protest, not only in the cultural sphere but also in the political sphere. But that was not the case in Cuba because critical voices in the cultural sphere were disconnected from dissident voices in the political sphere. On the one hand, the authorities and some critical voices organized this disconnection intentionally, but on the other hand, it also took place in unintentional and implicit ways because of a tacit and, at the same time, shared understanding about the limits of dissent.

This article argues that we need to understand how social and cultural claims are being both intentionally and unintentionally disconnected from political claims, in order to understand how the Cuban government has managed to prevent a more unified contentious movement from emerging until the late 2000s. We can explain this disconnection in three ways. Firstly, the Cuban government has strongly monitored political participation since the fall of the Berlin Wall, so as to prevent the emergence of challengers in the political sphere. Secondly, the authorities have channelled popular demands towards specific social and cultural issues in order to prevent other types of claims from being voiced (especially political claims). Thirdly and ultimately, the combination of selective repression and political opening has allowed for the continuous dismemberment of dissident movements.

The analysis draws on extensive fieldwork conducted in Havana, Cuba between 2005 and 2011). I first worked with an ethnographic method, living on a daily basis with the members of three contentious collectives that I had selected because of their already established existence (more than ten years), the relatively low turnover of their core groups, and the fact that they managed to obtain some official recognition from the Cuban state. These collectives are Cátedra Haydée Santamaría, a collective of young students, professors and intellectuals; Omni Zona Franca, a collective of self-taught artists and performers; and the hip-hop movement. I participated in all the collectives' meetings and activities (street performances, concerts, festivals, seminars, debates, etc.) that took place during my field trips; I collected extensive documentation about their history and activities (manifestos, programmes, press interviews, photos, videos, documentaries); and I conducted 2- to 3-hour interviews with each member. I also attended all the meetings and debates that took place in cultural institutions about social, cultural and political change in Cuba. During my last two 
field trips (2010 and 2011), I also interviewed the main figures of the new blogger movement, as well as several contentious networks that had recently emerged, including Observatorio Critico (libertarian socialists), Estado de Sats (liberals and reformists) and Arcoiris (a lesbian, gay, bisexual, transgender -- LGBT -- network). Eventually, I also systematically (on a daily basis) collected data on Cuban political debates, through press reviews and RSS flux from blogs and Cuban online news platforms.

\section{Monitoring Political Participation to Ensure Unity and Stability}

In the late 1980s there were contradicting trends in Cuba. Fidel Castro attempted to prevent Gorbatchov's reformist drive from reaching Cuban shores by launching 'the process of rectification of errors and negative tendencies' in 1986. His purpose was to invent an alternative way towards socialism and thus oppose the economic liberalization that was taking place in the Soviet Union. Despite Fidel Castro's move, the perestroika already had an influence on the Cuban political and intellectual spheres. Many Cubans were still studying in the Soviet bloc at the time, and they came home with reformist ideas. Party members were seduced by the possibility of reforming socialism in a more liberal way. And intellectuals, academics and artists were involved in collective projects, whose purpose was to discuss Cuba's future and give more autonomy (from political control) to academia and the cultural sphere. The government's way of dealing with this de facto heightened political participation and political interest was ambivalent. On the one hand, institutional channels for political participation were created; on the other hand, attempts at reforming Cuban socialism were curbed.

\section{Distinguishing Legitimate Political Participation from Illegitimate Political Claims}

In 1990, Fidel Castro announced that Cuba was about to confront a 'Special Period in times of peace $^{1}$ (i.e. a dire economic situation) because of the end of its trade agreement with the Soviet bloc. His discourse warned Cubans about the coming economic difficulties and claimed that unity should prevail more than ever in order to keep building socialism. He made it clear that socialist rule could not be challenged, but he also encouraged national debates ${ }^{2}$ about Cuba's future (Habel, 1991), although they were highly monitored.

Although debates took place throughout the country over more than a year (March 1990-October 1991), they were organized within a fixed framework provided by the party and mass organizations. People discussed quite freely, but they had no control over which ideas would be supported by the party delegates at the congress and which decisions would be made. Moreover, debates did not allow for the construction of public opinion, since the synthesis of those debates was only available to the political leadership. This pyramidal dimension of public debate can clearly be analysed as a strategy of power that allowed the Cuban government to obtain information in order to adjust to the changing economic and political situation, without opening up to more autonomous political participation. 
Initiatives 'from below' were not accepted as legitimate, even when they reclaimed the revolutionary legacy. For instance, groups that proposed decentralizing economic management in order to achieve long-term growth, enlarging political participation in order to fight bureaucratic inertia, or giving more autonomy to artistic creation (like Paideia, Tercera Opción or la Carta de los diez ${ }^{3}$ ) were harshly repressed either through physical harassment, imprisonment or exile. Artistic and intellectual projects were short-lived and rapidly dismembered after they were threatened and censored. The authorities refused to grant them the autonomy they claimed for the cultural sphere.

More surprisingly, even research conducted within the official academia was brutally censored. The paradigmatic example is that of the Centre for the Study of the Americas/Centro de Estudios sobre América - CEA). That research centre was institutionally linked to the Central Committee of the Communist Party. Its researchers were all party members. The Centre benefited from exceptional political protection and had few links with the Eastern European academia, so as to be able to work more freely with the Latin American academia (Dilla, 2011). In the 1990s, the CEA participated in the intellectual boom of the period and contributed to the coining of policies that would help renovate Cuban socialism despite the disintegration of the Soviet bloc. The researchers' objective was to elaborate new approaches to economics and politics, which could be directly useful to the Cuban political leadership. Economic liberalization and political participation were some of the key issues discussed.

CEA scientists gained fame in the Cuban intellectual milieu and abroad where foreign analysts were closely following what was happening in Cuba (Giuliano, 1998). This publicity and their links with foreign academia - which lent them some autonomy from the party thanks to invitations to international conferences, for instance-displeased the Cuban leadership (Alvarez \& Gonzalez Nuñez, 2001; Dilla, 2011). In March 1996, Raul Castro attacked the CEA on television, while reading the conclusions of the Fifth Party Plenum, which had just taken place. He stated that the CEA had become a fifth column inside Cuba, which worked hand-in-hand with enemies of the revolution, and that its activities would be terminated. All CEA researchers were individually relocated to other research centres.

We can here conclude that although debates were organized throughout the nation in the 1990s and the Fourth Party Congress was held with a more liberal atmosphere than previous congresses, the Cuban government managed to reassure its monopoly over Cuban politics by censoring and/or repressing all alternative projects in the early 1990s. Political authorities stressed in practice the distinction between legitimate and illegitimate ways of voicing concerns. All claims that were articulated outside the legitimate political framework (the Fourth Party Congress debates) - and especially those that managed to get international press coverage - were perceived and staged as threats to the necessary national unity. Publicity and autonomy were clearly condemned. Moreover, challenging socialism as a political project was not tolerated. Facing repression and imprisonment, dissenters were led to either self-censor or go into exile. In the 1990s, many chose to leave the country, which partly explains the small size and scope of dissident movements in Cuba until the end of the 2000s, compared to the same type of movements in the Soviet bloc. Eventually, the ability shown by 
the Cuban leadership to keep defining the legitimate political line throughout the difficult period of the 1990s heavily constrained the norms of discourse, and especially the norms of tolerated criticism, over the long term.

\section{Making Political Participation Local}

Social unrest had led to an increased interest in politics in Cuba during the 1990s. After the debates that took place in order to prepare for the Fourth Party Congress, public participation was channelled towards the local level. The decentralization of certain political responsibilities was put into place in order to relieve the national level of some of its tasks in a context of scarce public resources. The creation of Popular Councils, an intermediary institution between citizens and the local authorities, was part of this process. Driven by local delegates (from the municipal assembly), their aim was to better public management at the local level (water and electricity supplies, housing problems, economic activity, schools...) and to improve people's involvement in the making of decisions that would affect their daily lives (Dilla, Gonzalez \& Vincentelli, 1993).

But this kind of participation was limited to concrete issues at the very local level, without the possibility of questioning national policies that greatly determine how society is organized, including at the local level (Bengelsdorf, 1994; Azor \& Chaguaceda, 2011). Moreover, people were organized from above (just as in mass organizations); they were not encouraged to organize in a more autonomous way to frame or solve problems in their own way. Many anecdotes told by Cubans testify that autonomous organizing, even for the smallest things like repairing the electric motor of the water pump in a building, needs to go through the approval of local authorities. Political participation is thus restricted to consulting citizens, whereas decisions are taken at a higher level (Chaguaceda, Daubelcourt \& Gonzalez, 2012).

In that sense, Popular Councils seem to have taken on a similar role to the one played by CDRs (Committees for the Defence of the Revolution, the local level mass organization) during the first years after the 1959 revolution. Salas (1979) described it this way: 'a communication framework with the governed' for the Cuban political leadership. The Popular Councils are therefore no alternative to top-down power wielding, which prevents dissenting narratives, perspectives or organizations from emerging, and thus promote unity as the basis of the stability of the nation. Those who do dissent at the micro-social level are only allowed to do so if they accept that their activities must be framed as 'revolutionary' and that they will be closely scrutinized by local authorities and thus partly censored (Geoffray, 2012).

The 1990s can be characterized as ambivalent years in Cuba. There were many political debates, but they did not give way to more plural politics. Although we cannot really speak of a lack of political participation, the close monitoring of that participation is certainly one of the elements that helps explain political stability because it made it extremely difficult for challengers to emerge, become visible, organize and gain domestic and international legitimacy. On the contrary, the quasi impossibility to organize dissent led to the massive emigration of critical intellectuals, artists and political challengers. Nevertheless, the 
effervescence of the 1990s was not completely lost. Social and cultural claims were articulated and partly taken up by the Cuban leadership.

\section{Creating Tolerated Norms of Protest}

Despite (or because of) the closure of the political sphere, social unrest kept growing in Cuba, especially in Havana. Many Cubans chose to emigrate, especially renowned artists, intellectuals and academics, thus depriving the country of its best creative minds. To prevent this brain drain, the political leadership started dealing differently with artists and intellectuals from 1997 onwards, when Abel Prieto became culture minister. Prieto eased restrictions on traveling abroad and allowed some kind of laissez faire when issues that were not considered too political were being discussed within intellectual and artistic circles (Fernandes, 2006; Hernandez Reguant, 2010; Geoffray, 2012).

Government officials or party members even deliberately promoted social and cultural identity-based dynamics that used to be censored, such as afro-Cuban religions or gay rights. Two elements can explain this. On the one hand, there was more space for debate on such topics because state institutions were weaker and because more reformist, younger leaders were promoted to top positions in the party and mass organizations. On the other hand, such laissez faire can also be understood as a strategic move on the part of the Cuban leadership.

From the 1990s onwards, the Cuban human rights record had been negatively assessed by international organizations such as the United Nations (UN) and by non-governmental organizations (NGOs), such as Amnesty International. In order to counter those negative assessments, the Cuban government counted on the promotion of Cuban culture abroad, where it was widely acclaimed. The Cuban authorities' tolerance towards many critical art movements, such as hip-hop, can be understood within this framework. The government also started promoting its good ranking in the Human Development Index (0.7 in 1990; 0.8 in 2011, on a scale of zero to one), emphasizing the social and cultural rights granted to the Cuban citizens as a tactic to reject the characterization of the regime as a 'human rights violator'. Refusing the framing of human rights as primarily civil and political, the authorities started building a 'competitive frame' (Jetschke \& Liese, 2013) to impose a more social and cultural perspective of human rights. The authorities' promotion of gay rights is to be understood as part of that strategy.

\section{Professionalizing Rappers}

When hip-hop emerged in Cuba at the end of the 1990s, it represented a way for parts of the restless youth of Havana-who often came from marginal suburbs or inner city districts - to express feelings of rebellion against the dire social and economic condition in which they were living (Baker, 2005, 2006). They copied American rappers and break-dancers (hip-hop dance), asking for mass consumption and freedom of expression and claiming to be 'bad boys'. Race was not a prominent issue in their songs, although many young rappers 
considered themselves as coloured or black. Racial issues were seldom discussed in early Cuban rap, as it was seldom discussed in the Cuban society in general.

In 1962, Fidel Castro had proclaimed the end of racial discrimination, since racial apartheid (in public spaces, access to certain jobs or schools, etc.) had been abolished in Cuba. But racial prejudice was never eradicated because it was never publicly debated and prejudice was reproduced within families (de la Fuente, 2001). To counter the resurgence of racist prejudice in the 1990s, a few academics and intellectuals organized to promote public debate on that question, but they were not very successful ${ }^{4}$ until the emergence of the hip-hop movement. When those intellectuals realized that the young rappers were mostly coloured but that they knew little about black struggles, they decided to teach them. The academics invited the rappers to seminars, courses and private meetings at home in order to discuss the history of slavery, racial discrimination and the emergence of 'conscious rap' in the USA (Perry, 2004; Olavarria, 2008). After some time those meetings attracted attention from state security services and they were discontinued. Nevertheless, the discussions rappers had with those intellectuals echoed their experience of racial discrimination; their songs started to be inspired by their newly acquired knowledge. Still, this new consciousness did not transform into a critique of the lack of public debate on the matter or the lack of affirmative action policies. Neither did it transform into a race-based social movement, as some scholars had expected (Perry, 2004). Some rappers were offered membership in state institutions; others exited, or were marginalized.

In the early 2000s, some young rappers were offered the possibility to become recognized amateurs (as members of a national cultural youth institution: the Asociación Hermanos Saiz - AHS) and, sometimes, professional musicians (as members of the National Rap Agency, created in 2002). These possibilities to professionalize transformed the hip-hop movement. Whereas competition between rappers had until then taken place in a horizontal way (reputation was linked to prowess in terms of verbal flow), it started to be organized in a vertical way: rappers now competed with each other in order to be accepted as members of the AHS. Auditions were organized, and the selection board was composed of intellectuals and artistic figures who knew little about rap and were generally selected by the national board of the AHS for their interest in racial issues. Criteria explicitly favoured rappers who referred to Cuban colonial history and developed black aesthetics (use of conchas - seashells, boubous, braids), while paying allegiance to the Cuban revolution as an emancipatory project. On the contrary, rappers who were closer to American hip-hop (with more repetitive rhythms or more direct critique), and for whom the flow and the protest load of the lyrics mattered more, did not make it.

Most of the rappers I interviewed told me they found these selection boards to be illegitimate, but none called for a boycott of the auditions. And as many popular rappers were invited, little by little, to be part of these boards, they became part of the selection system. They were indeed put in a position in which they were given influence and power, which in turn meant that they needed to play the same game as the other members of the board, i.e. judge their fellow rappers according to aesthetic criteria. The responsibility given to these rappers had two effects: they had to engage in vertical relationships with cultural authorities, 
which contradicted the horizontal relationships they entertained among themselves; and they became socialized to the norms of tolerated criticism within the cultural sphere. Rap thus became a competitive and demanding professional activity, evaluated by legitimate artists and intellectuals, rather than a social or political movement. Professional rappers endorsed the official perspective according to which fifty years of revolution could not eradicate five hundred years of prejudice, exploitation and discrimination. And hip-hop started to be framed as a sui generi black artistic movement, a kind of heir to rebellious black culture under colonial rule, both in Cuba and abroad ${ }^{5}$.

Hip-hop is thus a relevant example to understand how contentious young voices were channelled towards certain issues, such as race, which allowed them to engage in 'safe radicalism' (Kapcia, 2000, p. 212). On the one hand, state agents strove to create 'institutionalized channels' (Oberschall, 1973, p. 245) for the expression of social protest, in order to isolate it from more political protest. On the other hand Cuban intellectuals and artists looked for respectable allies to expand their influence within the cultural sphere and rappers played the game because they looked for official 'recognition' (Grenier, 2011, p. 156). The result is that the intense competition created within the hip-hop movement successfully prevented rappers from interacting too intensely with other contentious and especially dissident movements ${ }^{6}$.

\section{Depoliticizing Gender}

Even before Mariela Castro (Raul Castro's daughter, head of the Cenesex - National Centre for Sexual Education) openly promoted a new approach to gay rights, gender issues had been part of some Cuban leaders' agenda for years (such as Vilma Espin, Mariela Castro's mother). Those issues had not gained public prominence because of the reluctant health ministry and state security services, as well as social prejudice (Hamilton, 2012). Although the situation has not changed dramatically, Mariela Castro is given space and leverage, within the Cuban leadership, to carry out her agenda. The National Assembly has passed a law that allows transsexuals to change identity and to be able to be operated on for free if they wish (Arreola, 2006). This initiative represents a great move away from the 1960s' state politics during which homosexuals were sent to re-education camps - an episode that still has not clearly been acknowledged as a mistake (Osorio, 2002). But those new rights are being granted to sexual minorities from above; they cannot really be reclaimed from below, nor are they publicly discussed. A good example of this is the organization of the first gay parade in Havana in 2008.

Mariela Castro organized the first rally against homophobia in Havana in May 2008. Although the march took place on a very limited portion of one single street, it was a landmark in Cuban politics, as it symbolically put an end to decades of state discrimination (homosexuals were constantly targeted and harassed by the police). However, that initiative was not connected to an open, plural and public discussion on the issue of gay rights and past state policies against them. Fidel Castro did make a statement in Mexican journal La Jornada in 2010 (Lira Saade, 2010), as well as Mariela Castro a year later, but both interviews were 
ambivalent. Fidel Castro stated that he had not had the time to pay attention to gay rights during the 1960s because of the preoccupying political issues he had to deal with. And Mariela Castro added that the 1960s' repression of homosexuals was the product of an especially difficult situation in Cuba after the Bay of Pigs invasion (1961) and the Missile Crisis (1962) (Arreola, 2011). Moreover, both statements were published abroad.

Despite these ambiguous stands, left-oriented, semi-autonomous groups, such as Observatorio Critico and Proyecto Arcoiris and moderate bloggers (i.e. critical but revolutionary) ${ }^{7}$ praise Cenesex for its bold attempt to introduce liberal political rights, such as identity based rights, into Cuban socialism. Notably, the mottos which are shouted during the yearly rallies organized by Mariela Castro, such as 'Homophobia no! Socialismo sí!', make it clear that those rights are articulated with the ideological framework of the Cuban revolution. Gay activists who would intend to challenge that ideological paradigm are censored and sometimes repressed. For instance, when Foundation LGTB Reinaldo Arenas in Memoriam attempted to organize its own gay parade in June 2008, it was prevented from doing so. Its aim was to deliver an open letter to the justice ministry, asking the Cuban state to apologize for the repression of homosexuals and HIV infected people and for the re-education camps. Its members were arrested and the march was forbidden ${ }^{8}$. A few years later, Mariela Castro also accused the founders of the independent LGBT observatory of having a 'political interest" ${ }^{\prime}$, that is, of linking gender and politics. Those are clear examples of the authorities' tactics to dissociate the sectorial campaign for homo/transsexual rights from state politics.

Both the space given to the hip-hop movement and race issues as well as the new prominence given to gender and sexuality testify to the Cuban government's new modes of authoritarian government: space is offered to certain groups and minorities to let them promote and discuss certain issues, but that space is carefully monitored in order to keep control over the way those issues make it into the public space. But this strategy is ambivalent. It has managed to generate relative support within Cuba and from outside Cuba because it is has helped create a more complex image of the socialist regime and contributed to reshaping political cleavages between those who give priority to civil and political rights and those who emphasize social and cultural rights. Mariela Castro's approach is clever because it proposes support those rights, as long as that support contributes to enlarging the popular basis for continued socialist rule. This approach allows Cuban authorities to isolate 'social' contention from 'political' dissidence because it pushes activists who want to engage in safe politics to work together with officials, even if they sometimes need to self-censor. In that sense, those activists actively participate in the maintenance of the constraints set by the authorities: abiding by their rules also means keeping distance from political dissent.

One of the consequences of the authorities' tolerance towards certain kinds of social and cultural activism is that the concerned artists, intellectuals and activists elaborate tactics in order to differentiate themselves from dissidents. They strive to protect the spaces they have obtained, and they can become censors themselves for that purpose. Some, for instance, let state security agents control entrance to debates, concerts or film screenings. Others take on the authorities' discourse about dissidents and denounce them as 'imperialist agents'. The semi-liberalization of critique and the promotion of certain cultural and social rights are 
therefore costly and are linked to the building of new norms of tolerated critique. Those who do not respect those norms are, at best, marginalized; they are often repressed. Under late socialism, the line which separates the censors and the censored is thus quite thin, since many incompliant citizens participate in the (re)production of the system of social and political control. They indeed play a game, the rules of which have been defined by the authorities, and which contributes to marginalizing political dissidents and to maintaining a clear dichotomy between those who are 'with the revolution' and those who are 'against the revolution'.

\section{Depoliticizing Communication on Highly Political Issues}

Channelling dissident hard-liners into depoliticized forms of participation happens to be a much more difficult task for authoritarian governments than is the case with more artistic and intellectual agents of contention. The dissidents can indeed generally count on the support of the international community of governments, multilateral institutions like the European Union or advocacy NGOs like Human Rights Watch and Amnesty International. Famous abroad for their direct political opposition to authoritarian governments, they cannot easily tone down their criticism without losing support and legitimacy. In Cuba, these confrontational politics have led many dissidents to be imprisoned for long jail terms. The most famous are the 75 dissidents imprisoned in 2003 under charges of 'activities against the integrity and sovereignty of the state' or 'acts against the independence or territorial integrity of the state ${ }^{10}$. Before the emergence of transnational political campaigns using new information and communication technologies (NICT), such repression bore few consequences for the Cuban government, which seemed to be immune to international pressure and was already suffering from a long-term embargo. This last part, analyses a specific moment of Cuban politics: the release of Cuban political prisoners in 2010. It is a particularly relevant example to show how the Cuban regime combines political openings, channelling strategies and repression in order to remain in power.

\section{Raul Castro's Softer Power: Between Political Opening and Repression}

During Fidel Castro's presidency, the political sphere was completely closed to political challengers. Dissidents were called 'mercenaries' and treated as such. Many were imprisoned for ordinary crimes such as theft, which they had supposedly committed (Linares Balsameda, 2009), and they were constantly denied the status of political prisoners, either in or out of jail.

With Raul Castro's rise to power, there was a political opening. First, Raul Castro allowed the release of a punk artist, who was going to be imprisoned under charges of 'criminal predisposition' (dangerosidad predelictiva in Spanish) ' 1 ' in August 2008, after a transnational online campaign in his favour (Hernandez Busto, 2008). One year later, Raul Castro acknowledged, for the first time, the existence of political prisoners in Cuba and said he was ready to discuss the issue with President Obama, as well as press freedom and human 
rights (Reuters, 2009) ${ }^{11}$. And in 2010, he agreed to free dozens of political prisoners, after another transnational campaign demanding their liberation.

At the same time, this opening in terms of public speech did not really translate into less repression. Harassment against political dissidents did not stop, and especially against the Ladies in White, the mothers and wives of the 75 political prisoners jailed in 2003, who were continuously harassed. Although the Cuban authorities were more cautious with them than with other movements (they generally sent female police to curb their protests ${ }^{12}$ ), police repression created uneasiness among many Cubans on the island, including Cubans considered as 'revolutionaries'. The authorities thus started to stage fake popular street protests (called actos de repudio - repudiation acts) by supposed pro-revolutionaries (again, mostly female) against the Ladies. Those fake protests had two purposes: They allowed the government to avoid taking responsibility for the repression the Ladies were subjected to, and they made it possible for the government to boast about the popular support given 'spontaneously' to the Cuban revolution by ordinary Cuban citizens (Manzaneda, 2010). Even foreign journalists cannot easily challenge such a perspective on the actos de repudio, because the participants they interview echo the government's interpretation of the actos and because they fear their visa might be revoked if they cross a red line (red lines being hard to define clearly) $)^{13}$.

Now, the fact that Cuban authorities attempt to control both the local and international perception of the repression they stage against dissidents shows that they have become more responsive to Cuban public opinion and to international pressure. Furthermore, Raul Castro's decision to free the political prisoners in July 2010 is probably linked to the impressive transnational outcry generated by the heightened repression ${ }^{14}$ that took place against the Ladies in White during the first part of 2010, when their movement gained strength and took to the streets on a regular basis. Nevertheless, Raul Castro managed to transform such a political move into an almost non-political event.

\section{Building a Humanitarian Framing for the Dissidents' Release}

The release of dozens of political prisoners at once was a rare political move in socialist Cuba. However, such an event was rapidly framed as 'humanitarian' and depoliticized. In order to understand how such a framing became dominant, we need to analyse the role of the Cuban Catholic Church, which was instrumental in the liberation of the political prisoners.

After thirty years of repression in atheist Cuba, the fall of the Berlin Wall prompted reforms in the 1990s. One of them was the decision taken by the government to reintegrate believers as full citizens with equal political rights in 1992, thanks to the amendments made to the constitution. From then on, the Catholic Church started to regain momentum (Létrilliart, 2005). Pope John Paul II visited the island in 1998, and the Church took on a more prominent role as far as social and charity work. Foundations (Felix Varela Center in Habana, Civic and Religious Education Centre in Pinar del Rio), and journals (Vitral, Espacio Laical) linked to the Church became spaces for social and political debates. 
When the Ladies in White created their organization, they asked the Catholic Church for support. The Saint Rita parish in Miramar - chosen because Rita is the Saint of desperate causes - offered them a 'safe space' (Gamson, 1996) to gather on a weekly basis from 2003 onwards. The Ladies' identity as a movement was influenced both by their fear of repression and by their relationship to the Church. In order to avoid being violently silenced, they chose to stage their claim as a claim for mercy ${ }^{15}$; they emphasized their identity of mater dolorosa ${ }^{16}$ and constantly refused to be characterized as a political movement ${ }^{17}$. This self-presentation made it costly for the Cuban authorities to repress them frontally. And when repression heightened during an intense week of protest they organized in March 2010, it led Cuban Cardinal Jaime Ortega to publicly condemn that as unjustifiable violence against women (Vicent, 2010a). Such a move from the Church was unexpected, as never before had the Church publicly stood up to defend political dissidents, and it prompted Raul Castro to meet the cardinal. A few months afterwards the first political prisoners started to be released.

Even more than the release of the prisoners per se, the contradictions between the way the prisoners were liberated and the public discourses held on such a political event are especially puzzling. Firstly, the prisoners' liberation was not framed as a political blow for the Cuban government. On the contrary, Raul Castro enhanced his image as a reformer, compared to his hard-line brother Fidel Castro. Secondly, the decision was not even framed as a political move. Indeed, the liberations were announced by Cardinal Jaime Ortega, not by Raul Castro himself $^{18}$, which channelled media attention towards the role of the Church and allowed for the reproduction of the Church's humanitarian framing of the issue (Vicent, 2010b) ${ }^{19}$. Thirdly, the conditions attached to the liberation of the prisoners - they were taken from prison directly into exile in Spain ${ }^{20}$-were little commented upon. On the contrary, the emigration of the first prisoners to Spain shifted media focus from their release to their migration status in Spain. Soon enough, the discrepancy between the dissidents' expectations and the Spanish government's help given to them to settle down was widely commented upon both in the traditional media and on blogs (because it was quite unjustly compared to the exceptional conditions granted to emigrating Cubans in Miami-conditions granted to no other minority in the US). Ultimately, the Spanish government started to be blamed for its poor management of the situation (O'Grady, 2011; Minder, 2012) ${ }^{21}$.

This communication strategy was a real masterstroke for the Cuban government. Raul Castro was not only framed as a reformer with a vision, he also managed to transform a highly controversial political issue into a humanitarian and migratory one. Although the Cuban government did yield to the specific demands of liberation made by the protesters, this move has not led to an acceptance of challengers in the political sphere. The two UN covenants on human rights signed by Cuba remain unratified, and repression against political dissidents has not lessened; it has rather transformed into less visible forms of harassment and threat.

Raul Castro's strategy is in line with former 1990s strategies of ousting critical voices. Letting dissidents - or rather, in that case, making them - exit the country meant less hassle and less unwanted (and negative) international attention for the Cuban government. Although 'exit' does not always mean absence of 'voice' (see Hoffmann, 2010 using Hirschman's 
distinction), contention from within is often key to bringing political change (the 1989 demonstrations and the Arab Springs are good examples). Moreover, the liberation of political prisoners led to divisions among the Ladies in White movement between those who decided to keep fighting for regime change and those who considered that their claim had been heard. Once again and despite the victorious outcome of the Ladies in White's struggle, spatial and political divisions have prevented a unified political movement from emerging in Cuba.

\section{Conclusion}

The Cuban case is especially relevant to contribute to a better understanding of the ways protest is being curbed in illiberal regimes. The Cuban government has indeed managed, on the one hand, to isolate cultural and social claims from political claims and. on the other hand, to channel citizen's political participation towards the local level, while giving a few signs of political aperture. As a result, political dissidents have been marginalized, and legitimate critical intellectuals and artists have emerged who are willing to negotiate with the authorities and thus contribute to the reproduction of the erected border between the sociocultural and the political spheres. Moreover, when opportunities are created for the formulation of political claims, they generally remain anchored at the local level, without leading to bottom-up dynamics. This strategy has managed to channel discontent towards issues that are thought of as safe enough in the Cuban context (race, gender and sexuality, religion) to be discussed. Attempts at organizing protest thus remain segmented across social sectors and territories and often depoliticized.

The Cuban example is helpful to understand other illiberal governments' strategies because it demonstrates that a sheer focus on censorship and repression is not sufficient to understand how challengers are tamed, social movements disbanded and claims managed. Indeed when repression actually works - that is, when protest is completely suppressed-it becomes invisible in such contexts (Earl, 2004; Combes \& Fillieule, 2011). We thus need to look at the social control of protest, i.e. at the ways protest is being channelled, so as to get a better understanding of how protesters manage to carve out a (limited) space for action (Earl, 2006), often without challenging authoritarian rule. In the Chinese case, the dispersion of claims and complaints on the internet is one of the main tools used by the government (Arsène, 2011). In Cuba, the government has managed to combine political opening, selective repression and channelling tactics in order to avoid the emergence of a unified contentious movement. More case studies are needed to analyse the whole range of ways implemented by illiberal regimes to curb protest, but the Cuban case already teaches us that the elaborate game of intended and unintended disconnections between the social and cultural claims and the political claims is key to better understanding how illiberal governments manage not to be too openly — or too visibly — challenged in systemic ways.

\section{References}


Alvarez Garcia, A. \& González Núñez, G. (2001) ¿Intelectuales vs revolución?: El caso del Centro de Estudios sobre América, CEA [Intellectuals vs. Revolution? The Case of the CEA] (Montreal: Ediciones Arte D.T.)

Arreola, G. (2006) Estudia parlamento cubano reconocer derechos a transsexuals [Cuban parliament willing to recognize rights of transsexuals], La Jornada, 12 August.

Arreola, G. (2011) Impulsan investigación en Cuba sobre abusos a homosexuales en las UMAP [Calls for investigation in Cuba of abuse of homosexuals in reeducation camps], La Jornada 12 August.

Arsène, S. (2011) Internet et politique en Chine [Internet and Politics in China] (Paris: Karthala).

Azor, M., Chaguaceda, A. (2011) Cuba, política de participación y practicas de autonomía: organización, acción y discurso [Cuba, participation policy and autonomous practices: organization, action and discourse], Revista Critica y Emancipación 3(6), pp. 9-35.

Baker, G. (2005) Hip Hop, Revolución! Nationalizing Rap in Cuba, Ethnomusicology, 49(3), pp. 368-402.

Baker, G. (2006) 'La Habana que no conoces'. Cuban rap and the social construction of urban space, Ethnomusicology Forum, 15(2), pp. 215-246.

Balasinski, J. (2002) Culture et politique en période de transition de régime: le cas du théâtre en Pologne dans les années 1980 et 1990, [Culture and politics in regime transition periods: the case of theatre in Poland 1980-1990], PhD dissertation, University Paris Ouest.

Bengelsdorf, C. (1994) The Problem of Democracy in Cuba: Between Vision and Reality (Oxford; Oxford University Press).

Bialer, S. (1980) Stalin's Successors: Leadership, Stability, and Change in the Soviet Union (Cambridge: Cambridge University Press).

Carillo, A. (2005) Arqueología del discurso de las élites cubanas sobre raza durante el siglo XX. Editoriales y articulos de opinion [Archeology of Cuban elite discourse regarding race during the $20^{\text {th }}$ century. Essays and opinion articles], $\mathrm{PhD}$ dissertation, University of Grenade.

Cavatorta, F. (ed.) (2013) Civil Society Activism under Authoritarian Rule (London and New York : Routledge).

Chaguaceda, A., Daubelcourt, D \& Gonzalez, L. (2012) Participación comunitaria en Cuba. Experiencias de un consejo popular [Community Participation in Cuba. Experiences of a Popular Council] (Berlin: Friedrich Ebert Stiftung).

Combes, H. and Fillieule, O. (2011) De la répression considérée dans ses rapports à l'activité protestataire : Modèles structuraux et interactions stratégiques, Revue Française de Science Politique, 61(6), pp. 1047-72.

Corrales, J. (2004) The gatekeeper state: limited economic reforms and regime survival, Latin American Research Review, 39(2), pp. 35-65.

De la Fuente, A. (2001) Race, Inequality and Politics in 20th Century Cuba, A Nation for All (Chapel Hill: University of North Carolina Press). 
Diaz Martinez, M. (2003) La carta de los diez, Cuba Encuentro, 23 July.

Dilla, H. (2011) Que pasó con el Centro de Estudios sobre America? [What happened to the CEA?], Cubaencuentro.24 March.

Dilla, H., Gonzalez, G. \& Vicentelli, A.T. (1993) Participación popular y desarrollo en los municipios cubanos [Popular Participation and Development in Cuban Municipalities] (La Habana: Centro de Estudios sobre América)

Earl, J. (2003) Tanks, tear gas, and taxes: Toward a theory of movement repression, Sociological Theory, 21(1), pp. 44-68.

Earl, J. (2004) Controlling protest: New directions for research on the social control of protest, Research in Social Movements, Conflicts and Change, 25, pp. 55-83.

Earl, J. (2006) Introduction: Repression and the social control of protest, Mobilization, 11(2), pp. 129-43.

Espina, M. (2011) Changes in the economic model and social policies in Cuba, Salvaging the Revolution, NACLA Report on the Americas.

Espina, M. (2008) Viejas y nuevas desigualdades en Cuba [Old and new inequalities in Cuba], Nueva Sociedad, 216. pp. 133-149

, F., Heller, A., \& Markus, G. (1983) Dictatorship over Needs: An Analysis of Soviet Societies (Oxford : Blackwell).

Fernandes, F. (2006) Cuba represent! Cuban arts, state power and the making of new revolutionary culture (Durham, NC.: Duke University Press)

Gamson, W. (1996) Safe places and social movement, Perspectives on Social Problems, 8, pp. 27-38.

Geoffray, M. L. (2012) Contester à Cuba [Protesting in Cuba] (Paris : Dalloz)

Giuliano, M. (1998) El Caso CEA. Intelectuales e inquisidores en Cuba: perestroïka en la isla? [The CEA Case. Intellectuals and Inquisitors in Cuba: Perestroika on the Island] (Miami: Ediciones Universal).

Habel, J. (1991) Rectification dans la rectification? [Rectification within the Rectification], Problèmes d'Amérique Latine, 99, pp. 3-16

Hamilton, C. (2012) Sexual Revolutions in Cuba. Passion, Politics and Memory (Chapel Hill: University of North Carolina Press).

Hernandez Busto, E. (2008) Gorki Aguila, liberado [Gorki Aguila, freed], Penultimos Dias, 30 August.

Hernandez Reguant, A. (2009) Cuba in the Special Period: Culture and Ideology in the 1990s (New York: Palgrave Macmillan).

Hewett, E. (1988) Reforming the Soviet Economy: Equality versus Efficiency (Washington, DC: The Brookings Institution).

Hoffmann, B. (2010) Bringing Hirschman back in: 'Exit', 'voice', and 'loyalty' in the politics of transnational migration, The Latin Americanist, 54(2), pp. 57-73

Jetschke, A. \& Liese, A. (2013) The power of human rights a decade after: from euphoria to contestation, in: T. Risse, S.C. Ropp, \& K. Sikkink (Eds), The Persistent Power of Human Rights: From Commitment to Compliance, pp. 26-42 (Cambridge : Cambridge University Press). 
Kapcia, A. (2000) Cuba: Island of Dreams (Oxford: Berg).

Létrilliart, P. (2005) Cuba, l'Eglise et la Révolution [Cuba, the Church and the Revolution] (Paris: l'Harmattan).

Linares Balsameda, J.C. (2009) Jailed dissident doctor to be charged, Miami Herald, 29 July.

Lira Saade, C. (2010) Soy el responsable de la persecución de homosexuales que hubo en Cuba [I am the one responsible for the persecution of homosexuals in Cuba], La Jornada, 31.08 .

Manzaneda, J. (2010) Desmontando el guion mediatico de las Damas de blanco [Unraveling the media guide of the Ladies in White], Cubadebate, 08.04.

Minder, R. (2012) Exile Cuban dissidents living in Spain feel abandoned as benefits dry up, New York Times, 1 June.

O'Grady, M.A. (2011) Spain betrays Cuba's dissidents, The Wall Street Journal, 13 June.

Olavarria, M. (2008) Rap and revolution, hip hop comes to Cuba, in: P. Brenner, M.R. Jimenez, J. Kirk, \& W. LeoGrande (Eds), A Contemporary Cuba Reader, pp. 369-372 (New York: Rowman \& Littlefield Publishers).

Osorio, R. (2002) Gays and the revolution: the case of Reinaldo Arenas, Latin American Perspectives, 29(2), pp. 78-98.

Pacini Hernandez, D. \& Garofalo, R. (1999) Hip hop in Havana: Rap, race and national identity in contemporary Cuba, Journal of Popular Music Studies, 11-12(1), pp. 18-47.

Popa, I. (2001) 'L'impureté' consentie. Entre esthétique et politique: critiques littéraires à Radio Free Europe, [Consenting to 'impurity'. Between Aesthetics and Politics: Literary Critique at Radio Free Europe], Sociétés et representations, 11, pp. 55-75.

Perry, M. (2004) Rap, Race and Social Transformation in Contemporary Cuba, PhD dissertation (Austin : University of Texas).

Perez-Stable, M. (1999) The Cuban Revolution: Origins, Course, and Legacy (Oxford: Oxford University Press).

Risse, T., Ropp, S. C. \& Sikkink, K. (Eds) (1999) The Power of Human Rights: International Norms and Domestic Change (Cambridge: Cambridge University Press).

Rodriguez, A. (2004) Authorities force protesters linked to Cuban dissidents out of Havana park, Associated Press, $[7$ October

Salas, L. (1979) Social Control and Deviance in Cuba (New York: Praeger).

Vaissié, C. (1999) Pour votre liberté et pour la nôtre, le combat des dissidents de Russie [For Your Freedom and For Ours, Dissidents' Struggle in Russia], (Paris, Robert Laffont).

Vaissié, C. (2008) Les ingénieurs des âmes en chef, littérature et politique en URSS (19441986) [Engineers of Souls, Literature and Politics in the USSR (1944-1986)], (Paris, Belin).

Vicent, M. (2010a) La iglesia catolica pide cuanto antes cambios a Raúl Castro [The Catholic Church asks Raul Castro for reforms as soon as possible], El País, 21 April.

Vicent, M. (2010b) Raúl Castro habla con el cardenal Jaime Ortega sobre la excarcelación de presos politicos [Raul Castro speaks with Cardinal Jaime Ortega about prisoners' release], El Pais, 20 May. 
West-Duran, A. (2004) Rap's diasporic dialogues: Cuba's redefinition of blackness, Journal of Popular Music Studies, 16(1), pp. 4-39.

\section{Endnotes}

1 See Fidel Castro's discourse in January 1990:

http://www.cuba.cu/gobierno/discursos/1990/esp/f280190e.html

${ }^{2}$ Call for the Fourth Party Congress, launched in March 1991. He especially urged social scientists to better contribute to ongoing social and political debates. See full text at: http://congresopcc.cip.cu/wp-content/uploads/2011/02/Llamamiento-al-IV-Congreso.pdf

3 See Cubista Magazine's special issue on Paideia and Tercera Opción (http://cubistamagazine.com/dossier.html), and Manuel Diaz Martinez's (2003) article 'La carta de los diez' featuring a letter by a group of writers and journalists sent to the government, asking for economic reforms and more democracy. (Its main protagonist, Maria Elena Cruz Varela, was imprisoned for two years between 1992 and 1994 before she could go into exile).

${ }^{4}$ Fidel Castro still rejoiced at the idea that racial discrimination had been abolished in Cuba in a speech delivered in 1997. Quoted by Anton Carrilo (2005), see pp. 411-428.

${ }^{5}$ Most scholars focused on rap as a black movement (Pacini \& Garofalo, 1999; West-Duran, 2004; Perry, 2004; Fernandes, 2006) without deconstructing the way it became framed as such. Geoff Baker $(2005,2006)$ showed that this perspective was not shared by many rappers, who did not endorse that perspective and continued to discuss other issues, especially freedom of expression, urban marginalization and the lack of economic reform in the Cuban society.

${ }^{6}$ There were exceptions like famous duo Los Aldeanos, Raudel (Eskuadrón Patriota), Ángel Yunier (El Critico)...

7 Observatorio Critico, www.observatoriocriticoblogspot.org, Proyecto Arcoiris, http://proyectoarcoiris.wordpress.com/ and blogger Negra Cubana, http://negracubanateniaqueser.wordpress.com

8 'Cuba's first gay pride parade cancelled', The Guardian, 26 June, 2008

9 'Activistas crean un observatorio para promover los derechos de la comunidad LGBT', Diario de Cuba, 26 May, 2011.

${ }_{10}$ See report by Committee to Protect Journalists http://www.unhcr.org/refworld/country,,CPJ,,CUB,,47c5669b23,0.html

${ }^{11}$ Raul Castro: Cuba ready for US talks on rights, prisoners, Reuters, 17 April, 2009.

12 See pictures of their removal from the Plaza on their website: http://www.latinamericanstudies.org/damas.htm and a press account: Rodriguez (2004).

${ }^{13}$ Interview with Sara Roumette, ex-journalist for Radio France in Cuba, [2 November 2011]. Fear of revocation is linked to concrete censorship and repression against foreign journalists. 
The Center for the International Press can revoke the 'accreditation' given to foreign journalists for lack of 'objectivity' or 'ethics'. Several journalists had their accreditation revoked in the last years, with renowned El Pais correspondent Mauricio Vicent being the last of a series. See 'El régimen cubano retira la acreditación al corresponsal de El País en La Habana', El Pais, 4 September, 2011.

${ }^{14}$ US secretary of state Hillary Clinton and US President Barack Obama, as well as Chile's President Sebastian Piñera, ex-Polish President Lech Walesa and the French, Spanish and Canadian governments were some of the most prominent personalities who asked the Cuban government to put an end to the repression against the Ladies in White and to free their husbands and sons.

${ }^{15}$ See their presentation of themselves here: 'Esposas de presos hablan con un hijo de Castro', Associated Press, La Havana, 12 June 2004]

16 'Cuba Mother's Day March Seeks Dissidents' Release', Reuters, La Havana. 9 May 2004

${ }^{17}$ See Lady in White Laura Pollan's interview on BBC Mundo, 17 March, 2010.

18 'Gobierno cubano anuncia a través de iglesia liberación de 52 prisioneros políticos', Nuevo Diario, 7 July, 2010.

19 See his press conference in Palabra Nueva, http://www.palabranueva.net/contens/noticias2010/pn_1017.pdf,

${ }^{20}$ Agence France Press comments that only dissidents who accepted to go into exile in Spain were liberated. 'Dudas en Cuba sobre las condiciones de excarcelación de presos que rechazan exiliarse', 16 November, 2010.

${ }^{21}$ See also 'Cuban exiles unhappy in Spain', Radio Netherlands Worldwide, 9 August 2011 